\title{
Kecernaan ransum broiler yang mengandung kombinasi kunyit, bawang putih dengan mineral zink
}

\author{
M.N. Regar* dan Y.H.S. Kowel \\ Fakultas Peternakan Universitas Sam Ratulangi Manado, 95115 \\ *Korespondensi (corresponding author): mursyeregar@ unsrat.ac.id
}

\begin{abstract}
ABSTRAK
Penelitian ini bertujuan untuk mengetahui nilai kecernaan protein dan energi ransum yang mengandung kombinasi kunyit, bawang putih dengan mineral zink. Sebanyak 20 ekor broiler umur 5 minggu digunakan dalam penelitian ini. Percobaan menggunakan rancangan acak lengkap (RAL) dengan 4 perlakuan dan 5 ulangan. Formula ransum perlakuan terdiri dari : $\mathrm{R} 1=$ Ransum basal, R2= Ransum basal + serbuk kunyit 1,5\% + ZnO 180 ppm, R3=Ransum basal + serbuk bawang putih 2,5\% + ZnO 180 ppm, R4= Ransum basal + antibiotik. Pengukuran kecernaan dilakukan dengan metode total koleksi dengan peroide penyesuaian selama 5 hari dan pengambilan data selama 3 hari. Variabel yang diamati adalah konsumsi protein, kecernaan protein dan energi ransum. Hasil penelitian menunjukkan bahwa perlakuan kombinasi kunyit dengan mineral zink, kombinasi bawang putih dengan minaral zink, dan kombinasi ransum basal dengan antibiotik nyata memperngaruhi kecernaan protein tetapi tidak mempengaruhi konsumsi protein dan kecernaan energi. Dapat disimpulkan bahwa ransum yang mengandung kombinasi kunyit, bawang putih dengan mineral zink menghasikan nilai kecernaan protein dan energi yang baik
\end{abstract}

Kata kunci: ayam broiler, kunyit, bawang putih, mineral zink, kecernaan

\begin{abstract}
DIGESTIBILITY OF BROILER RATIONS CONTAINING THE COMBINATION TURMERIC, GARLIC WITH THE ZINC MINERALS. This study aims to determine the digestibility value of protein and energy rations containing a combination of turmeric, garlic and zinc minerals. A total of 20 broilers aged 5 weeks were used in this study. The experiment used a completely randomized design (CRD) with 4 treatments and 5 replications. The treatment ration formula consisted of: $\mathrm{R} 1=$ basal ration, $\mathrm{R} 2=$ basal ration + turmeric powder $1.5 \%+\mathrm{ZnO} 180 \mathrm{ppm}, \mathrm{R} 3=$ basal ration $+2.5 \%$ garlic powder $+\mathrm{ZnO} 180 \mathrm{ppm}, \mathrm{R} 4=$ basal ration + antibiotics. Digestibility measurement was done by total collection method with adjustment period for 5 days and data collection for 3 days. The variables observed were protein consumption, protein digestibility and ration energy. The results showed that the combination treatment of turmeric with zinc minerals, the combination of garlic and zinc mineral, and the combination of basal ration with antibiotics significantly affected protein digestibility but did not affect protein consumption and energy digestibility. It can be concluded that the combination of turmeric, garlic with the mineral zinc results in good protein digestibility and energy.
\end{abstract}

Keywords: broiler chicken, turmeric, garlic, zinc minerals, digestibility 


\section{PENDAHULUAN}

Daging broiler merupakan salah satu pangan yang dikonsumsi secara luas, sebagai sumber protein dan lemak dalam jumlah besar di Indonesia untuk semua usia (anak-anak maupun dewasa) karena daging broiler mudah diperoleh dan harganya yang relatif murah. Pemeliharaan broiler pada umumnya masih menggunakan obatobatan, dan ransum dengan imbuhan seperti antibiotik dan hormon digunakan untuk mencapai produk yang optimal. Penggunaan antibiotik dalam ransum ternak bertujuan sebagai pemacu pertumbuhan, untuk memperbaiki efisiensi penggunaan ransum dan pencegahan terhadap kemungkinan infeksi patogen. Permasalahan yang timbul dalam bisnis beternak ayam adalah mulai dilarangnya penggunaan antibiotic growth promotor (AGP), karena memungkinkan adanya residu dari antibiotik dalam produk peternakan, yang akan menjadi racun bagi konsumen (Daud, 2005). Maka dari itu antibiotik alami yang aman diperlukan karena tidak meninggalkan residu yang berbahaya.

Tanaman herbal dikenal masyarakat Indonesia sejak dulu sebagai obat maupun untuk memperbaiki metabolisme. Penggunaan kombinasi kunyit, bawang putih dengan mineral zink dalam ransum menjadi salah satu alternatif untuk mengatasi masalah tersebut. Kunyit memiliki keunggulan yang mampu memperbaiki pencernaan ayam broiler, membantu memperbaiki jaringan tubuh dan menjaga daya tahan tubuh. Senyawa yang terkandung dalam kunyit adalah senyawa Curcuminoid yang memiliki kegunaan sebagai antioksidan (Rezki et al., 2015; Yarru et al., 2009; Adegoke et al., 2018; Jena et al., 2020), dan minyak atsiri yang bersifat sebagai pemusnah bakteri dan mengandung sifat anti inflamasi atau anti radang (Suirta et al., 2016). Komponen aktif dalam bawang putih, allicin merupakan zat aktif yang mempunyai daya bunuh pada bakteri dan antiradang (Ao et al., 2011; Varmaghany et al., 2015); alliin merupakan suatu asam amino antibiotik dan menurunkan kolesterol darah dan daging broiler (Jaya, 1997). Mineral zink dalam bentuk zink inorganik mempunyai fungsi meningkatkan performans dan respon imun terhadap broiler (Ali et al., 2003; Olukosi et al., 2018; AkhavanSalamat dan Ghasemi, 2019).

Kecernaan suatu bahan adalah bagian yang terserap dalam saluran pencernaan dan tidak dieksresikan dalam feses (McDonald et al., 2010). Titus dan Fritz (1971) menyatakan bahwa tidak semua bahan ransum dapat dicerna dengan baik. Kegunaan penentuan kecernaan adalah untuk mendapatkan nilai bahan ransum secara kasar, sebab hanya bahan ransum yang dapat dicerna yang dapat diserap. Kecernaan kombinasi kunyit, bawang putih dan mineral zink dalam ransum ayam broiler belum pernah dilakukan, oleh karena itu penelitian ini dilakukan untuk melihat kecernaan dari kombinasi herbal terseebut dengan mineral zink.

\section{MATERI DAN METODE PENELITIAN}

Penelitian ini menggunakan rancangan acak lengkap (RAL) yang terdiri dari 4 perlakuan 5 ulangan, menggunakan ayam broiler umur 5 minggu sebanyak 20 ekor. Periode penyesuaian ransum dilakukan selama 5 hari dan pengambilan data dilakukan selama 3 hari dengan metode total koleksi. Data yang diperoleh dianalisis sidik ragam (ANOVA), bila terdapat perbedaan yang nyata dilakukan uji lanjut dengan Uji Beda Nyata Jujur (BNJ). Ransum yang digunakan adalah ransum komersial, yang selanjutnya disebut ransum basal. Ransum basal kemudian dicampur dengan serbuk kunyit, serbuk bawang putih, dan mineral zink dalam bentuk $\mathrm{ZnO}$. Formula ransum perlakuan terdiri dari : $\mathrm{R} 1=$ Ransum basal, R2= Ransum basal + serbuk kunyit $1,5 \%+\mathrm{ZnO}$ 180 ppm, R3=Ransum basal + serbuk 
Tabel 1. Komposisi Nutrien Ransum Perlakuan

\begin{tabular}{lccccccc}
\hline Perlakuan & $\begin{array}{c}\text { ME } \\
\text { Kcal/kg }\end{array}$ & $\begin{array}{c}\text { Protein } \\
\text { Kasar } \\
(\%)\end{array}$ & $\begin{array}{c}\text { Serat } \\
\text { Kasar } \\
(\%)\end{array}$ & $\begin{array}{c}\text { Lemak } \\
\text { Kasar } \\
(\%)\end{array}$ & $\begin{array}{c}\text { Ca } \\
(\%)\end{array}$ & $\begin{array}{c}\text { P } \\
(\%)\end{array}$ & $\begin{array}{c}\text { Zn } \\
(\%)\end{array}$ \\
\hline R1 & 3073 & 22,62 & 3,21 & 10,21 & 1,80 & 0,72 & 0,005 \\
R2 & 3235 & 22,38 & 3,11 & 9,46 & 1,32 & 0,62 & 0,017 \\
R3 & 3188 & 22,35 & 2,73 & 11,15 & 1,90 & 0,61 & 0,015 \\
R4 & 3073 & 22,62 & 3,21 & 10,21 & 1,80 & 0,72 & 0,005 \\
\hline
\end{tabular}

bawang putih $2,5 \%+\mathrm{ZnO} 180$ ppm, $\mathrm{R} 4=$ Ransum basal + antibiotik. Variabel yang diukur adalah konsumsi protein, kecernaan protein dan energi. Kecernaan protein, yaitu jumlah protein tercerna dinyatakan dalam satuan persen (\%) dan dihitung dengan rumus menurut Anggorodi (1995).

\section{Kecernaan protein}

Keterangan:

$$
=\frac{(A x B)-(C x D)}{(A x B)} \times 100 \%
$$

$\mathrm{A}=$ Jumlah konsumsi ransum

$\mathrm{B}=\%$ protein dalam ransum

$\mathrm{C}=$ Jumlah ekskreta

$\mathrm{D}=\%$ Protein ekskreta

Energi metabolis dihitung dengan rumus

(Scott et al., 1982) sebagai berikut :

$$
E M S=\frac{G E \text { intake }-G E \text { eksreta }}{\text { intake }}
$$

Keterangan :

EMS $=$ Energi metabolis semu $(\mathrm{kkal} / \mathrm{kg})$

GE intake $=$ Gross energi ransum dalam konsumsi $(\mathrm{kkal} / \mathrm{kg})$
GE ekskreta $=$ Gross energi dalam ekskreta (kkal/kg)

Intake $=$ Konsumsi ransum

\section{HASIL DAN PEMBAHASAN}

Konsumsi protein yaitu jumlah protein yang dikonsumsi oleh ayam broiler, dinyatakan dalam satuan gram (Tillman et al., 1998). Data nilai konsumsi protein, kecernaan protein dan kecernaan energi dapat dilihat pada Tabel 2. Hasil analisis keragaman untuk konsumsi protein tidak menunjukkan adanya perbedaan $(\mathrm{P}>0.05)$. Nilai konsumsi protein berkisar antara 12,75 - 13,07 g. Konsumsi protein tidak berbeda dikarenakan kandungan protein ransum yang hampir sama yaitu berkisar $22 \%$. Menurut Winedar et al. (2004) bahwa semakin tinggi kandungan protein ransum maka akan semakin tinggi pula konsumsi protein, namun jika kandungan protein relatif sama maka konsumsi protein akan sama. Menurut pendapat Wahju (1997) bahwa konsumsi protein dipengaruhi oleh konsumsi ransum dan kandungan protein dalam ransum yang diberikan.

Tabel 2. Rataan Konsumsi Protein, Kecernaan Protein dan Energi Metabolis Ransum Perlakuan

\begin{tabular}{lllll}
\hline \multirow{2}{*}{ Variabel } & \multicolumn{4}{c}{ Perlakuan } \\
\cline { 2 - 5 } & $\mathrm{R} 1$ & $\mathrm{R} 2$ & $\mathrm{R} 3$ & $\mathrm{R} 4$ \\
\hline Konsumsi Protein $(\mathrm{g})$ & 12,75 & 12,80 & 12,81 & 13,07 \\
Kecernaan Protein $(\%)$ & $71,75^{\mathrm{b}}$ & $75,04^{\mathrm{a}}$ & $75,05^{\mathrm{a}}$ & $75,67^{\mathrm{a}}$ \\
Energi Metabolis $(\mathrm{kcal} / \mathrm{kg})$ & 3260,40 & 3271,50 & 3247,60 & 3245,30 \\
\hline
\end{tabular}

Keterangan : Superskrip berbeda pada baris yang sama menunjukkan perbedaan yang nyata $(\mathrm{P}<0.05)$ 
Hasil analisis ragam pengaruh perlakuan terhadap kecernaan protein menunjukkan perbedaan yang nyata $(\mathrm{P}<0.05)$. Rataan nilai kecernaan protein berkisar antara $71,75-75,67 \%$. Uji lanjut BNJ menunjukkan bahwa perlakuan menggunakan kombinasi kunyit dengan mineral zink (R2), kombinasi bawang putih dengan mineral zink (R3) dan ransum basal denga antibiotik (R4) tidak menunjukkan adanya perbedaan. Ramadhani et al. (2017) menyatakan bahwa senyawa Curcuminoid, kebanyakan berupa curcumin yang mempunyai kegunaan sebagai anti oksidan. Fungsi kunyit untuk meningkatkan kerja organ pencernaan unggas adalah merangsang dinding kantong empedu mengeluarkan cairan empedu dan merangsang keluarnya getah pankreas yang mengandung enzim amilase, lipase, dan protease yang berguna untuk meningkatkan pencernaan bahan ransum seperti karbohidrat, lemak, dan protein. Ditambahkan pula oleh Wahju (1997) bahwa bahan ransum yang dicampur zat additive berfungsi untuk meningkatkan proses metabolisme dalam tubuh, sehingga zat-zat makanan tersebut dapat dikonsumsi, dicerna, diabsoorpsi dan ditransportasikan ke seluruh tubuh dengan lancar. Hanen et al. (2012), komponen antioksidan pada bawang paling besar berasal dari phenolic, flavonoid dan vitamin $\mathrm{C}$, sedangkan organosulfur memiliki peran penting sebagai antibakteri. Komponen antibakteri paling besar dari bawang putih berasal dari organosulfur yang berupa Allicin.

Hasil analisis keragaman pengaruh perlakuan terhadap kecernaan energi tidak menunjukkan adanya perbedaan. Saputra $e t$ al. (2001) kecernaan energi matabolis dipengaruhi oleh gross energy ransum dan banyaknya energy yang digunakan oleh ternak. Standar kebutuhan nutrisi untuk energi metabolis dipengaruhi oleh suhu lingkungan, mekanisme adaptasi suhu lingkungan pada unggas dapat dilihat dari kemampuan mengkonsumsi ransum adanya mekanisme termodinamik yang mengontrol pemasukan dan pengeluaran energi ke dalam dan keluar tubuh berfungsi untuk menstabilkan suhu tubuh (Anggarayono et al., 2008).

\section{KESIMPULAN}

Ransum yang mengandung kombinasi kunyit, bawang putih dengan mineral zink menghasilkan nilai kecernaan protein dan energi yang baik.

\section{DAFTAR PUSTAKA}

Adegoke, A.V., M.A. Abimbola, K.A. Sanwo, L.T. Egbeyale, J.A. Abiona, A.O. Oso, S.O. Iposu. 2018. Performance and blood biochemistry profile of broiler chickens fed dietary turmeric (Curcuma longa) powder and cayenne pepper (Capsicum frutescens) powders as antioxidants. Veterinary and Animal Science 6 :95-102.

Akhavan-Salamat, H. dan H.A. Ghasemi. 2019. Effect of different sources and contents of zinc on growth performance, carcass characteristics, humoral immunity and antioxidant status of broiler chickens exposed to high environmental temperatures. Livestock Science 223:76-83

Ali, S.A., M.A.M. Sayed, S.A. El-wafa, G. Abdallah. 2003. Performance and immune response of broiler chick as affected by methionine and zinc or commercial zink-methionine supplementations [abstrak]. J. Egypt Poult. 23(3): 523-540.

Anggarayono, H. I., Wahyuni dan Tristiarti. 2008. Energi metabolis dan kecernaan protein akibat perbedaan porsi pemberian pakan pada ayam petelur. Dalam. Bamualim, M. A., A. Thalib, Y. N. Anggraeni, Mariyono, Samsul, B., Takahiro, T. (Ed). Prosiding Seminar Nasional Teknologi Peternakan dan Veteriner. Bogor, 11 - 12 Nopember 2008. Hal. 623-629. 
Anggorodi, H. R. 1995. Nutrisi aneka ternak unggas. Gramedia Pustaka Utama, Jakarta.

Ao, X., J.S. Yoo, T.X. Zhou, J.P. Wang, Q.W. Meng, L. Yan, J.H. Cho, I.H. Kim. 2011. Effects of fermented garlic powder supplementation on growth performance, blood profiles and breast meat quality in broilers. Livestock Science 141 (2011) 85-89

Daud, M. 2005. Performan Ayam Pedaging yang Diberi Probiotik dan Prebiotik dalam Ransum. Jurnal Ilmu Ternak 5(2):75 - 79

Hanen, N., S. Fattouch, E. Ammar dan M. Neffati. 2012. Allium species, ancient health food for the future. Scientific, Health and Social Aspects of the Food Industry 343-354

Jaya, I.N.S. 1997. Pengaruh penambahan bawang putih (Allium sativum L.) dalam ransum pada kadar kolesterol ayam broiler. Tesis. Program Pascasarjana, Institut Pertanian Bogor.

Jena, S., A. Ray, A. Sahoo, P.C. Panda, S. Nayak. 2020. Deeper insight into the volatile profile of essential oil of two Curcuma species and their antioxidant and antimicrobial activities. Industrial Crops \& Products 155, 112830

McDonald, P., R.A. Edwards, J.F.D. Greenhalg, C.A. Morgan, L.A. Sinclair, R.G. Wilkinson. Animal Nutrition. Pearson.

Olukosi, O.A., S.V. Kuijk, Y. Han. 2018. Copper and zinc sources and levels of zinc inclusion influence growth performance, tissue trace mineral content, and carcass yield of broiler chickens. Poultry Science 97:38913898

Ramadhani, P., E. Erly, A. Asterina. 2017. Hambat ekstrak etanol rimpang kunyit (Curcuma domestica V.) terhadap pertumbuhan bakteri Staphylococcus aureus secara In
Vitro. Jurnal Kesehatan Andalas 6(3):590-595

Rezki, R.S., D. Anggoro, M.Z. Siswarni. 2015. Ekstraksi multi tahap kurkumin dari kunyit (Curcuma domestica Valet) menggunakan pelarut etanol. Jurnal Teknik Kimia USU 4 (3):29-34

Saputra, P. H., O. Sjofjan dan I. H. Djunaidi. 2001. Pengaruh penambahan fitobiotik meniran (Phyllanthus niruri,L.) dalam pakan terhadap kecernaan protein kasar dan energy metabolis ayam pedaging. Disertasi. Universitas Brawijaya. Malang.

Scott, M. L., M. C. Nesheim dan R. C. Young. 1982. Nutrition of the Chicken. M.L. Scott Assocites. Ithaca, New York.

Suirta, I.W., N.M. Puspawati, I.R.A. Asih. 2016. Aktifitas antiinflamasi topikal minyak atsiri dan ekstrak eter tumbuhan tenggulun, Protium Javanicum, Burm terhadap model inflamasi kulit pada tikus. Cakra Kimia (Indonesian E-Journal of Applied Chemistry) 4(1):8-17.

Tillman, A., H. Hartadi, S. Reksohadiprodjo, S. Prawirokusumo, S. Lebdosoekodjo. 1998. Ilmu Makanan Ternak Dasar. Gadjah Mada University Press. Yogykarta.

Titus, H.W. dan J.C. Fritz. 1971. The Scientific Feeding of Chickens. 5Ed. The Interstate Printers \& Publishers, Inc. Danville, Illinois.

Varmaghany, S., M.A.K. Torshizi, S. Rahimi, H. Lotfollahian, M. Hassanzadeh. 2015. The effects of increasing levels of dietary garlic bulb on growth performance, systolic blood pressure, hematology, and ascites syndrome in broiler. Poultry Science 94:1812-1820

Wahju, J. 2004. Ilmu Nutris Unggas. Edisi ke-4. Gadjah Mada University Press, Yogyakarta.

Winedar, H., S. Listyawati, Sutarno. 2006. Daya cerna protein pakan, kandungan 
Zootec Vol. 41 No. 1 : 311 - 316 (Januari 2021) $\quad$ pISSN 0852 - 2626 eISSN 2615 - 8698

protein daging, dan pertambahan berat badan ayam broiler setelah pemberian pakan yang difermentasi dengan Effective Microorganisms-4 (EM-4). Jurnal Bioteknologi. 3(1):14-19.

Yarru, L. P., R.S. Settivari, N.K.S. Gowda, E. Antoniou, D.R. Ledoux, G.E. Rottinghaus. 2009. Effects of turmeric (Curcuma longa) on the expression of hepatic genes associated with biotransformation, antioxidant, and immune systems in broiler chicks fed aflatoxin. Poultry Science 88:2620-2627 